\title{
Distribution of responsibility areas in a construction company
}

\author{
Ruslan Minnullin ${ }^{1, *}$, and Alla Larkina ${ }^{2}$ \\ ${ }^{1}$ Tyumen Industrial University, Volodarskogo St., 38, Tyumen, 625000, Russia \\ ${ }^{2}$ Samara State Technical University, Molodogvardeyskaya street, 244, Samara, Russia
}

\begin{abstract}
As of today, a huge number of sales management tools in a construction company are developed. This article proposes the use of a summary matrix of responsibility areas with the distribution of tasks among participants. This matrix is based on the functional fields of each participant in the process. The article presents a practical example of a compiled matrix of distribution of responsibility areas for the Sales Department of the house-building company Snegiri LLC, which was successfully tested. One of the advantages of the proposed toolkit is the possibility of its use for any working group and structural division of a company in any industry.
\end{abstract}

\section{Introduction}

In recent years the processes of globalization and integration occur in the economy and society, they significantly affect the conditions of functioning of economic entities in the residential real estate construction sector. In the Russian residential real estate market there are a large number of major house-building companies with the sales coverage in several regions. At the same time, the formation of one's own sales network has become, on the one hand, a necessary measure that allows developers to function effectively and, on the other hand, has led to the increased competition in the real estate market. In these conditions it becomes urgent to increase the competitiveness of house-building companies by improving the sales system. This problem can be solved through the effective analysis and planning of sales activities, competent personnel management, the use and control of internal resources of a construction company, which is the essence of the sales management process.

Sales management has certain specifics related to the scale of a house-building company, its organizational structure, geographic reach, market segments and other factors. However, there are common organizational and economic aspects of building a sales system, following which is the key to the competitiveness of this business.

Realizing the importance of the indicated problem, more and more foreign and domestic scientists touch upon the development of a competitive sales system within the company in their works. Thus, the works of such authors as G. Bolt, V. Danenburg, D. Jober, G. Jones, N. Rekhem, D. Sichelli, R. Spiro, C. Fatrell and many others are dedicated to the study of

\footnotetext{
* Corresponding author: minnullinaay@yandex.ru
} 
the sales management process [1-8]. They provide a deeper understanding of the theoretical aspects of the organization of commodity distribution networks, the formation and assessment of effective sales channels and sales personnel management. Nevertheless, specific methodological approaches to the formation of organizational structures and internal sales management regulations are poorly represented.

M. Avdeev, D. Borovinsky, A. Veshchekin, S. Edemskaya, V. Eliferov, I. Makurin and others offer non-standard solutions of the studied issues in the conditions of the development of competition in the Russian market $[9,10]$. However, they did not find the solution to improving the sales management system in house-building companies, supported by a specific methodological toolkit and different practical applicability.

\section{Methods}

Sales management in a house-building company is primarily determined by internal regulations, which should delimit the areas of responsibility of the personnel performing sales functions. For this purpose it is recommended to create functional fields for each participant in the sales process $\left(Y_{j}, j=\overline{1, m}\right)$. These fields can be formed in the form of a table (Table 1) or a graphic drawing (Figure 1) for clarity and convenience of daily practical use. The number of functional fields $\left(\sum_{l=1}^{L} P_{l}, l=\overline{1, L}\right)$ is determined by the number of tasks solved by a sales process participant $\left(\sum_{i=1}^{n} Z_{i}, i=\overline{1, n}\right)$.

The set of tasks solved by a sales process participant is the area of responsibility of this participant $\left(\mathrm{S}=\sum_{i=1}^{n} Z_{i}\right)$.

The functional field includes two components: the problem solved by a sales process participant and the step-by-step instruction for its solution $\left(\sum_{r=1}^{R} A_{r}\right)$. In this case the following condition must be fulfilled: $P_{l}=Z_{n}>Y_{m}$.

It should also be noted that a specific functional field contains a certain number of steps.

Table 1. The tabular form of the functional field of a sales process participant.

\begin{tabular}{|c|c|c|}
\hline $\mathrm{A}_{3}$ & $\mathrm{~A}_{4}$ & $\mathrm{~A}_{5}$ \\
\hline $\mathrm{A}_{2}$ & $\mathrm{Z}_{\mathrm{i}}$ & $\mathrm{A}_{\ldots}$ \\
\hline $\mathrm{A}_{1}$ & & $\mathrm{~A}_{\mathrm{r}}$ \\
\hline
\end{tabular}

The tabular form of the functional field of a sales process participant is convenient in the case of periodic adjustments and/or filling in the results of the tasks in the electronic version.

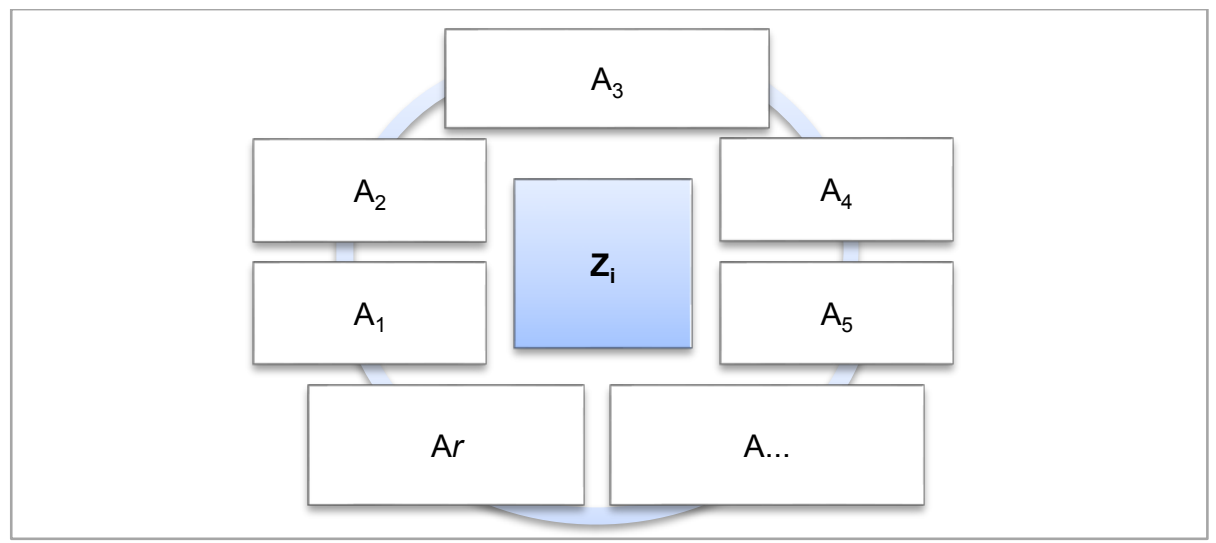

Fig. 1. Graphic form of the functional field of a sales process participant. 
Then a matrix of responsibility areas is compiled along with the distribution of tasks among all sales process participants (specialists performing sales functions) (Table 2). This matrix should always be available to all sales process participants and may contain a condition of responsibility for the task performed (development, participation, coordination).

Table 2. Matrix of responsibility areas with the distribution among sales process participants.

\begin{tabular}{|l|l|l|l|l|l|}
\hline Sales process participants & $\begin{array}{c}\text { Participant } \\
1\end{array}$ & $\begin{array}{c}\text { Participant } \\
2\end{array}$ & Participant 3 & $\begin{array}{c}\text { Participant } \\
\ldots\end{array}$ & $\begin{array}{c}\text { Participant } \\
\mathrm{m}\end{array}$ \\
Area of responsibility & & & & & \\
\hline Task 1 & & & & & \\
\hline Task 2 & & & & & \\
\hline Task 3 & & & & & \\
\hline Task 4 & & & & & \\
\hline Task 5 & & & & & \\
\hline Task $\ldots$ & & & & & \\
\hline Task $n$ & & & & & \\
\hline
\end{tabular}

In this case, three types of nuclei (cells) are noted in the matrix:

- "dark core" - determines the $j$-th sales process participant, who is assigned the $i$-th task in the area of responsibility;

- "light core" - determines the $j$-th sales process participant, who is indirectly involved in performing the $i$-th task in the area of responsibility;

- "empty core" - determines the lack of responsibility of the $j$-th sales process participant in the $i$-th task.

To control the implementation of all tasks in a timely manner, this matrix can be placed on an information board or be automated using the MS Excel spreadsheet and filled in by each participant in the company's local network.

\section{Results}

To test the proposed methodology, the distribution of responsibility areas was carried out on the example of the Sales Department of the house-building company Snegiri LLC operating in Tyumen.

Within the organizational structure the company has its own Sales Department consisting of the following specialists:

1) Commercial Manager;

2) head of the Sales Department;

3) specialists of the Sales Department;

4) lawyer;

5) assistant (paperwork assistant).

For the testing of a method of distribution of areas of responsibility the functional fields were drawn up for the distribution of areas of responsibility of the head of the Sales Department of Snegiri LLC.

The main tasks of the head of the Sales Department include as follows:

1. Execution of the monthly sales plan

2. Timely and correct work with CRM and phone calls. 
3. Organized and coordinated work of specialists in sales offices with customers

4. Preserving and increasing the volume of transactions involving credit funds of banks. Implementation of the program of work with a partner channel (real estate agency).

Figure 2 presents the functional field of the head of the Sales Department of Snegiri LLC for Goal 1.

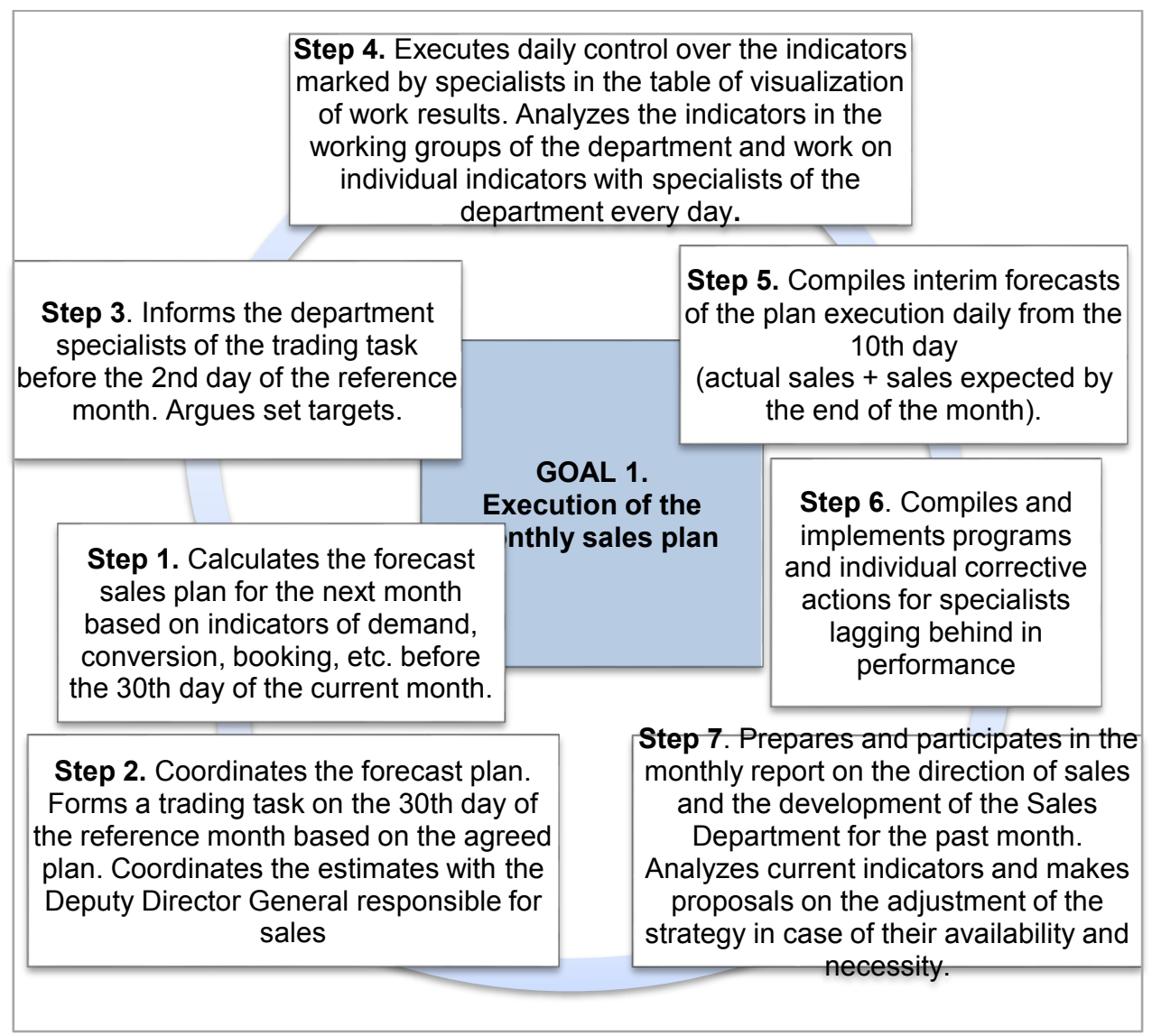

Fig. 2. The functional field of the head of the Sales Department of Snegiri LLC for the goal "Execution of the monthly sales plan".

Figure 3 presents the functional field of the head of the Sales Department of Snegiri LLC for Goal 2, also in graphical form. 
Step 4. Controls and evaluates the implementation by specialists of the Sales Department

of standards of the work with phone calls from buyers.

Compiles a program to adjust the work of a specialist.

Step 3. Controls pricing, organizes price adjustments in case of release of reservation

(made at the same price). Controls the observance of the difference between the selling price
GOAL 2.

Timely and correct work with CRM and phone calls.

Step 1. Organizes and controls the processing of missed calls. Organizes the operational processing of client requests and requests for a callback in

CRM. Draws up a report on responsible specialists.

Step 2. Daily controls the timeliness and correctness of reflection of the information in CRM by employees at all stages of work with clients (shows/presentations, block of arrangements, booking, sales recording), as well as controls the cancellation of sales, in case of the client's refusal to deal

Fig 3. The functional field of the head of the Sales Department of Snegiri LLC for the goal "Timely and correct work with CRM and phone calls".

For the comparative assessment of the use of the tabular form of the functional field in tables 3, 4, the functional fields of the head of the Sales Department of Snegiri LLC are presented for goals 3 and 4 respectively.

Table 3. The functional field of the head of the Sales Department of Snegiri LLC for the goal "Organized and coordinated work of specialists in sales offices with customers".

\begin{tabular}{l|l|l|}
$\begin{array}{l}\text { Step 3. Compiles and fills in the work } \\
\text { schedule for specialists for a month based on } \\
\text { the work schedule of specialists. Controls the } \\
\text { performance and makes adjustments and } \\
\text { replacements in case of changes (hospital, } \\
\text { replacement). }\end{array}$ & $\begin{array}{l}\text { Step 4. Controls the } \\
\text { preservation of material } \\
\text { values in sales offices. }\end{array}$ & $\begin{array}{l}\text { Step 5. Controls the observance of labor } \\
\text { discipline by an employee (dress code, } \\
\text { condition and order of workplaces, execution } \\
\text { of orders, regulations and orders for the } \\
\text { company). }\end{array}$ \\
\hline $\begin{array}{l}\text { Step 2. Distributes the work of specialists on } \\
\text { weekends, forms the duty on holidays, } \\
\text { organizes the preparation and signing of } \\
\text { orders on these duties. }\end{array}$ & $\begin{array}{l}\text { Organized and } \\
\text { coordinated work of } \\
\text { specialists in sales offices } \\
\text { with customers }\end{array}$ & $\begin{array}{l}\text { Step 6. Controls the functioning and } \\
\text { equipment of sales offices. Organizes modern } \\
\text { materials and tools for work, organizes } \\
\text { regular cleaning, water availability, } \\
\text { and office equipment. }\end{array}$ \\
$\begin{array}{l}\text { Step 1. Compiles a monthly schedule of work } \\
\text { of specialists in sales offices, taking into } \\
\text { account the vacation and interchangeability } \\
\text { schedule. Informs the specialists of the } \\
\text { schedule and monitors its fulfillment. }\end{array}$ & $\begin{array}{l}\text { Step 7. Organizes the functional distribution } \\
\text { of work between specialists. Improves the } \\
\text { efficiency of the work of specialists by the } \\
\text { method of operational load distribution in } \\
\text { case of an increase in the volume of } \\
\text { documents to be prepared. }\end{array}$ \\
\hline
\end{tabular}


Table 4. Functional field of the head of the Sales Department of Snegiri LLC for the goal "Preserving and increasing the volume of transactions with the involvement of credit funds of banks. Implementation of the program of work with a partner channel (real estate agency)".

\begin{tabular}{|l|l|l|}
\hline $\begin{array}{l}\text { Step 3. Analyzes the efficiency of } \\
\text { the distribution of mortgage } \\
\text { applications by a mortgage } \\
\text { specialist. }\end{array}$ & $\begin{array}{l}\text { Step 4. Organizes the process of } \\
\text { acceptance (checking the correctness of } \\
\text { filling) and distribution of primary } \\
\text { documents from real estate agencies by } \\
\text { performed transactions by assistants of } \\
\text { the Sales Department. }\end{array}$ & $\begin{array}{l}\text { Step 5. Initiates and participates in } \\
\text { ongoing marketing activities (press } \\
\text { tours, exhibitions, demonstrative onsite } \\
\text { presentations). }\end{array}$ \\
\hline $\begin{array}{l}\text { Step 2. Forms and controls the } \\
\text { implementation of the schedule for } \\
\text { the training of specialists of partner } \\
\text { agencies. }\end{array}$ & $\begin{array}{l}\text { Goal 4. } \\
\text { Preserving and increasing the volume } \\
\text { of transactions with the involvement of } \\
\text { credit funds of banks. Implementation } \\
\text { of the program of work with a partner } \\
\text { channel (real estate agency) }\end{array}$ & $\begin{array}{l}\text { Step 6. Addresses the emerging issues } \\
\text { with the directors of real estate agencies } \\
\text { (regarding payment, signing of } \\
\text { contracts, individual situations) }\end{array}$ \\
\hline $\begin{array}{l}\text { Step 1. Analyzes the effectiveness } \\
\text { of the work of a partner channel, } \\
\text { draws a monthly performance } \\
\text { report, sends the result to the } \\
\text { partners. }\end{array}$ & $\begin{array}{l}\text { Step 7. Participates in joint marketing } \\
\text { campaigns with partner banks. Analyzes } \\
\text { and generates proposals to improve the } \\
\text { efficiency of cooperation and the } \\
\text { number of joint sales. }\end{array}$ \\
\hline
\end{tabular}

Matrices with functional fields for the rest of specialists of the Sales Department are draw up similarly in an easy-to-use form (tabular/graphical form).

The set tasks and planned results of the step-by-step execution of tasks are recorded in the summary matrix of areas of responsibility of the Sales Department (Table 7).

Table 5. The summary matrix of areas of responsibility of the Sales Department of Snegiri LLC.

\begin{tabular}{|l|l|l|l|l|c|}
\hline \multirow{2}{*}{$\begin{array}{l}\text { Tasks of the Sales } \\
\text { Department }\end{array}$} & $\begin{array}{c}\text { Commercial } \\
\text { Manager }\end{array}$ & $\begin{array}{c}\text { Head of the } \\
\text { Sales } \\
\text { Department }\end{array}$ & $\begin{array}{c}\text { Specialists } \\
\text { of the Sales } \\
\text { Department }\end{array}$ & Lawyer & $\begin{array}{c}\text { Paperwork } \\
\text { assistant }\end{array}$ \\
\hline $\begin{array}{l}\text { Execution of the monthly } \\
\text { sales plan }\end{array}$ & Coordination & & Participation & & \\
\hline $\begin{array}{l}\text { Timely and correct work } \\
\text { with CRM and phone calls }\end{array}$ & & & Participation & & Participation \\
\hline $\begin{array}{l}\text { Organized and coordinated } \\
\text { work of specialists in sales } \\
\text { offices with clients }\end{array}$ & & & & Participation & Participation \\
\hline $\begin{array}{l}\text { Preserving and increasing } \\
\text { the volume of transactions } \\
\text { with the involvement of } \\
\text { credit funds of banks. }\end{array}$ & Coordination \\
$\begin{array}{l}\text { Implementation of the } \\
\text { program of work with a } \\
\text { partner channel (real estate } \\
\text { agency). }\end{array}$ & & & & & \\
\hline
\end{tabular}

\section{Conclusions}

A summary matrix of areas of responsibility and functional fields can be formed and applied to any working group and structural unit of a company in any industry. The use of this tool is a convenient and affordable option of a clear division of functions and powers between company employees. Each employee performs his/her own set of tasks and, therefore, the loss of time for finding out the responsible person and level of responsibility is reduced.

To control the fulfillment of all tasks on time this matrix can be placed on an information board or be automated using the MS Excel spreadsheet and filled in by each participant in the company's local network. 


\section{References}

1. M. Avdeev, Ways to reduce costs of transportation and storage of goods by distribution companies 4, 38-43 (2000)

2. A. Minnullina, A. Mottaeva, IOP Conference Series: Earth and Environmental Science, 90, 012123 (2017) doi:10.1088/1755-1315/90/1/012123

3. N. Zotkina, A. Kopytova, M. Zenkina, O. Zhigunova, MATEC Web of Conferences 106, 08058 (2017) doi: 10.1051/matecconf/201710608058

4. V. Lezier, M. Gusarova, A. Kopytova, IOP Conference Series: Earth and Environmental Science 90(1), 012034 (2017) doi: 10.1088/1755-1315/90/1/012034

5. N. Zotkina, S. Bardasov, M. Gusarova, A. Kopytova, MATEC Web of Conferences 106, 08050 (2017) doi: 10.1051/matecconf/201710608050

6. A. Minnullina, R. Abdrazakov, Advances in Intelligent Systems and Computing 692, 1224-1233 (2018) doi: 10.1007/978-3-319-70987-1_131

7. A. Minnullina, V. Vasiliev, E3S Web of Conferences 33, 03060 (2018) doi:10.1051/e3sconf/20183303060

8. N. Zotkina, M. Gusarova, A. Kopytova, Advances in Intelligent Systems and Computing 692, 1204-1213 (2018) doi: 10.1007/978-3-319-70987-1_129

9. V. Lezier, M. Gusarova, A. Kopytova, IOP Conference Series: Earth and Environmental Science 90(1), 012069 (2017) doi: 10.1088/1755-1315/90/1/012069

10. A. Minnullina. MATEC Web of conference 106, 08067 (2017) doi: $10.1051 /$ matecconf $/ 201710608067$ 